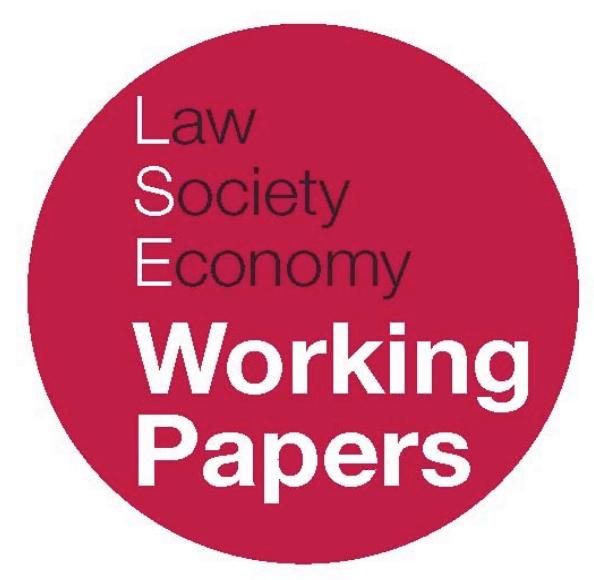

\title{
Independent Fiscal Institutions in \\ Comparative Constitutional Perspective
}

\author{
Cal Viney and Thomas Poole
}

LSE Law, Society and Economy Working Papers 12/2018

London School of Economics and Political Science

Law Department

This paper can be downloaded without charge from LSE Law, Society and Economy Working Papers at: www.lse.ac.uk/collections/law/wps/wps.htm and the Social Sciences Research Network electronic library at: http://ssrn.com/abstract $=3203960$

(C) Cal Viney and Thomas Poole. Users may download and/or print one copy to facilitate their private study or for non-commercial research. Users may not engage in further distribution of this material or use it for any profit-making activities or any other form of commercial gain. 


\title{
Independent Fiscal Institutions in Comparative Constitutional Perspective
}

\author{
Cal Viney and Thomas Poole*
}

\begin{abstract}
Independent fiscal institutions (IFIs), also known as independent budget offices, fiscal policy councils or independent fiscal watchdogs, have become a feature of the regulatory landscape since the global financial crisis. This paper analyses their proliferation and seeks to situate them in their constitutional and institutional environment. The paper begins with an assessment of the two competing rationales for their existence: first, the rationale of overcoming deficit bias in advanced western democracies (through institutions of de-politicisation), and second, the rationale of overcoming information asymmetry on two planes elector/government fiscal information asymmetry and legislature/executive information asymmetry (strategies of re-politicisation). The paper then analyses the legal and technical design features of two IFIs: the UK Office for Budget Responsibility (OBR) and the Australian Parliamentary Budget Office (PBO). We hypothesise that whatever their origin, IFIs will seek to add functions, that these will include both inward-facing functions (e.g. official economic forecasting) and outward-facing functions (e.g. election policy costings), and that this expansion is likely to be facilitated by inter-party competition. We conclude that the IFI is best understood as a distinctive attempt to devise a fiscal self-binding mechanism in the interests of securing intergenerational constitutional justice.
\end{abstract}

\footnotetext{
* Cal Viney is an Australian lawyer and currently serves as a Senior Adviser to the Premier of Victoria, Australia. Thomas Poole is Professor of Law at the London School of Economics \& Political Science. The authors would like to thank David Kershaw, Martin Loughlin and Niamh Moloney for their detailed and helpful comments and criticisms on an earlier version of the paper.
} 


\section{I.INTRODUCTION}

This paper examines the rise of the independent fiscal institution (IFI). A new feature of the regulatory landscape in most of the jurisdictions where they are to be found, these institutions are designed to encourage fiscal responsibility on the government's exercise of its budgetary responsibilities. The IFI often forms part of post-Global Financial Crisis (GFC) regulatory architecture ${ }^{1}$ and is familiar to students of political economy and financial regulation. But even though their activities relate directly to government in a way that is less true of other post-GFC innovations, IFIs have been largely ignored in the specialist public law literature, a by-product of the tendency among public lawyers to overlook the political economy dimensions of their field. ${ }^{2}$

This paper, the first of a projected series, seeks to bring the IFI into the public law fold. The project in general seeks to map the terrain for the benefit of public lawyers and to consider the institution from the perspective of public law. This paper provides a fine-grained comparative analysis of two examples of the genre that were introduced at roughly the same time: the UK Office for Budget Responsibility (OBR) and the Australian Parliamentary Budget Office (PBO). It examines the origins, duties and functions of the two institutions - but not at this point their effectiveness ${ }^{3}$ - and the way they have developed since their introduction. Our focus is to situate these bodies within their constitutional and institutional environment. This aim has influenced the process of selection.

The paper provides a detailed comparative analysis of the selected bodies, framed by a general discussion of the rise of the IFI as a distinctive fiscal and political institution. But we work out from those studies towards some conclusions, tentatively advanced at this stage, about the constitutional or public law significance of the IFI. Our analysis of the OBR and the PBO shows how these bodies were set up for slightly different, if overlapping, reasons, and that their responsibilities and functions are correspondingly distinctive, again overlapping. But it also suggests some underlying commonalities, the most important of which is that they offer a technocratic attempt at counterbalancing the short-term bandwidth of modern fiscal politics. On the basis of this observation, we argue that the IFI ought to be

\footnotetext{
${ }^{1}$ See Eilís Ferran, Niamh Moloney, Jennifer G. Hill and John C. Coffee, Jr, The Regulatory Aftermath of the Global Financial Crisis (Cambridge: Cambridge University Press, 2012); Julia Black, 'Paradoxes and Failures: “New Governance”" Techniques and the Financial Crisis' (2012) 75 Modern Law Review 1037. 2 See Gillian E. Metzger, 'Through the Looking Glass to a Shared Reflection: The Evolving Relationship between Administrative Law and Financial Regulation' (2015) 78 Law \& Contemporary Problems 129, 145: 'in the 1960 s and 1970 s ... as financial regulation dropped off the political and administrative [law] radar, it became more identified with the business and private-law side of law schools ... This academic division has meant that scholars from each field often have limited familiarity with the analytic paradigms and core concerns that dominate the other, further reinforcing their divergence.'

${ }^{3}$ As such, we do not discount the possibility that IFIs in practice turn out to be window dressing examples of virtue signaling on the part of governments facing pressure from bewildered citizenries postGFC and looking to shore up (or restore) confidence in their fiscal decision-making competence.
} 
understood as an institutional expression of what we call intergenerational constitutional justice. It provides, that is, a technology by means of which the interests and concerns of future generations are given voice and forced upon the consciences of today's decision makers.

\section{THE RISE OF THE INDEPENDENT FISCAL INSTITUTION}

Independent Fiscal Institutions (IFI) - or independent parliamentary budget offices, fiscal policy councils or independent fiscal watchdogs as they are all but interchangeably termed - exist to provide independent and authoritative analysis of the public finances. ${ }^{4}$ The International Monetary Fund (IMF) has employed the following broad definition:

a permanent agency with a statutory or executive mandate to assess publicly and independently from partisan influence government's fiscal policies, plans and performance against macroeconomic objectives relating to the long-term sustainability of public finances, short-medium-term macroeconomic stability, and other official objectives. In addition, a fiscal council can also (i) contribute to the use of unbiased macroeconomic and budgetary forecasts in budget preparation, (ii) facilitate the implementation of fiscal policy rules, (iii) cost new policy initiatives, and (iv) identify sensible fiscal policy options, and possibly, formulate recommendations. ${ }^{5}$

Applying this definition identifies thirty-nine IFIs globally ${ }^{6}$ (including eighteen within the OECD). ${ }^{7}$ IFIs of one sort or another have existed for decades in countries such as Belgium (1936), the Netherlands (1945), Denmark (1962), Austria (1970) and the United States (1974). But most owe their origins to the surge in government deficits and debts during the 2008-9 global financial crisis (GFC), which gave impetus to the suggestion that states should apply some of the experience of independent central banking to the fiscal sphere. Governments resorted to the IFI in part to lend legitimacy to their fiscal decision-making, and bound up in the reaction to the socialisation of fiscal risk that was such a feature of post-crisis politics, draws support from the evidence: the number of IFIs has more than tripled since the GFC. The largest growth can be seen in the European Union (EU)

\footnotetext{
${ }^{4}$ IFIs are 'independent public institutions with a mandate to critically assess, and in some cases provide non-partisan advice on, fiscal policy and performance': Lisa von Trapp, Ian Lienert and Joachim Wehner, 'Principles for Independent Fiscal Institutions and Case Studies' (2015) 2 OECD Journal on Budgeting, 11.

5 Xavier Debrun and Tidane Kinda, 'Strengthening Post-Crisis Fiscal Credibility: Fiscal Councils on the Rise - A New Dataset' (IMF Working Paper WP 14/58, International Monetary Fund, April 2014 ), 9. ${ }^{6}$ International Monetary Fund, 'Fiscal Councils Data Set', IMF Website, http://www.imf.org/external/np/fad/council/ (statistics as of end of December 2016).

7 Von Trapp et al, 10.
} 
following reforms in the fiscal framework, ${ }^{8}$ part of 'the massive reform agenda' undertaken by the EU in respect of its financial markets supervision and regulatory structures. ${ }^{9}$ Outside the EU, new IFIs have been set up - as in Canada (2008) and Australia (2011) - to increase fiscal transparency and enhance the role of the legislature in the budget process.

\section{RATiOnAle 1: DeFicit Bias}

Specific reasons for introducing an IFI vary according to national context, a point our case studies will illustrate. But two general (related but not subsumable) rationales tend to be advanced to explain the potential contribution of the IFI from a political economy standpoint. One prominent rationale offers the IFI as a technology for certain 'credible commitment' problems that pertain in this area, specifically the tendency of governments to depart from the long-term interests of the populace in fiscal sustainability for short-term gain, electoral popularity, or sectional interest. The argument connects the IFI to the persistence in advanced economies of deficits across the economic cycle. Robert Hagemann notes that this is a long-term trend: 'the overall fiscal balance of OECD economies, as well as in the large majority of its member countries, was in deficit throughout virtually the entire three decades to $2007^{\prime} .{ }^{10}$ This is a problem in as much as one subscribes to the macro-economic theory that government should run a counter-cyclical fiscal policy (i.e. deficits in a recession and surpluses in boom times so that public debt is kept stable across the economic cycle). ${ }^{11}$ Yet the persistence of deficits indicates a different practice - 'a tendency to adopt and implement pro-cyclical positions during cyclical upswings, resulting in high levels of public debt.' 12

On this rationale, the problem the IFI responds to is a predisposition to favour tax and spend policies that produce deficits at all times within the economic cycle

\footnotetext{
8 According to the Treaty on Stability, Coordination and Governance 2012 (TSCG), euro area member states must have an independent body to monitor compliance with national fiscal rules. For analysis of the TSCG see Paul P. Craig, 'The Stability, Coordination and Governance Treaty: Principle, Politics and Pragmatism' (2012) 37 European Law Review 231. The requirement to have IFIs was subsequently enhanced by the so-called 'two-pack' set of EU Regulations: EU Regulation 472/2013 on the strengthening of economic and budgetary surveillance of euro area members states experiencing or threatened with serious difficulties with respect to financial stability (EU Budget Surveillance Regulation); and EU Regulation 473/2013, which set out a common budgetary timeline applying to all euro area states for the publication and adoption of national medium-term fiscal plans and draft budgets. As part of this process, all euro area states were required to establish IFIs by October 2013 (EU Budget Monitoring and Assessing Regulation). For analysis see Sergio De la Parra, 'The Two Pack on Economic Governance: An Initial Analysis' (Background Analysis, European Trade Institute, Brussels 2013).

${ }^{9}$ Niamh Moloney, 'Reform or Revolution? The Financial Crisis, EU Financial Markets Law, and the European Securities and Markets Authority' (2011) 60 International \& Comparative Law Quarterly 521, 523. ${ }^{10}$ Robert Hagemann, 'How Can Fiscal Councils Strengthen Fiscal Performance?' (2011) 1 OECD Journal: Economic Studies 75, 77.

${ }^{11}$ As one might expect, this model is contested. For an entry into the debate see James M. Buchanan and Richard A. Musgrave, Public Finance and Public Choice: Two Contrasting Visions of the State (Cambridge, Mass: MIT Press, 1999).

12 Hagemann, 77.
} 
arising from the tendency among elected politicians 'not to consolidate the budget during good times in order not to hurt their electorates'. ${ }^{13}$ The intuition is that politicians, perceiving the importance of economic conditions for electoral success, will generate a 'political business cycle' so as to foster favourable conditions at election time. ${ }^{14}$ It represents as such an example of the principal-agent problem that looms large in the public finance literature. ${ }^{15}$ The term 'deficit bias' often deployed in such analyses trades on the idea of 'inflation bias' used in the monetary policy context which postulates that governments are unlikely to stick to long-term inflation targets due to time inconsistency pressures (the notion that policy makers' short-term objectives, such as adjusting interest rates in response to rising unemployment, conflict with the long-term objective of price stability, ${ }^{16}$ a problem said to be amplified in democracies $\left.{ }^{17}\right)$. Some economists argued that monetary policy functions-including the decision and execution of that policy, not just advice - should be outsourced to independent central banks, ${ }^{18}$ a proposal that had significant take-up in practice. ${ }^{19} \mathrm{By}$ analogy, ${ }^{20}$ some argue that IFIs can address some of the presumed causes of deficit bias, including information asymmetry (both between voters and politicians and between the legislature and the executive), economic forecasting bias (the tendency among governments to over-optimism in their economic forecasts ${ }^{21}$ ) and time inconsistency (as defined above). ${ }^{22}$

\footnotetext{
${ }^{13}$ Jurgen von Hagen, 'Scope and Limits of Independent Fiscal Institutions' in George Kopits (ed.), Restoring Public Debt Sustainability: The Role of Independent Fiscal Institutions (Oxford: Oxford University Press, 2013), 38. This relates to the practice of 'deficit finance': expenditure is raised in a context where additional outlays are deficit-financed (rather than through raising taxes). On this scenario, the principal of today in effect colludes with its agent to put the cost burden on the principal of tomorrow.

${ }^{14}$ Richard A. Musgrave and Peggy B. Musgrave, Public Finance in Theory and Practice (New York: McGrawHill, $5^{\text {th }}$ ed., 1989), 105.

${ }^{15}$ For an application of the insights of public finance theory into the domain of constitutions and constitutional arrangements see Jean-Jacques Laffont, Incentives and Political Economy (Oxford: Oxford University Press, 2000).

16 Charles Wyplosz, 'Fiscal Policy: Institutions versus Rules' (2005) 191 National Institute Economic Review 64, 67: 'the long-term discipline objective is systematically overlooked when short term discretion is being used'. But see Wren-Lewis, 'Comparing the Delegation of Monetary and Fiscal Policy', 58-62 and Xavier Debrun, 'Democratic Accountability, Deficit Bias and Independent Fiscal Agencies' (IMF Working Paper WP/11/173, International Monetary Fund, 2011) 10, both rejecting the claim that the specific type of time inconsistency that applies to inflation bias also applies to deficit bias.

17 Paul Tucker, Unelected Power: The Quest for Legitimacy in Central Banking and the Regulatory State (Princeton: Princeton University Press, 2018), 130: 'elected politicians face a bit of a problem in committing to a stable and prudent debt management strategy because their expected life in office is so much shorter than the life of the debt'.

${ }^{18}$ See e.g. Charles Goodhart, The Evolution of Central Banks (Cambridge, MA: MIT Press, 1988); Tucker, Unelected Power.

${ }^{19}$ See e.g. Christopher Crowe and Ellen E. Meade, 'The Evolution of Central Bank Governance around the World' (2007) 21 Journal of Economic Perspectives 69.

20 See e.g. Simon Wren-Lewis, 'Comparing the Delegation of Monetary and Fiscal Policy' in Koptis, Restoring Public Debt Sustainability.

${ }^{21}$ Lars Calmfors and Simon Wren-Lewis, 'What Should Fiscal Councils Do?' (2011) 26 Economic Policy 651.

22 Other problems associated with deficit bias include government impatience - governments know their time in power is limited and are therefore unlikely properly to internalise the long-term implications of fiscal decisions - and the 'common pool' problem - that those who press governments for increased spending, or greater tax cuts, fail to internalise the overall costs of higher spending and debt. See Paul
} 


\section{RATIONALE 2: INFORMATION ASYMMETRY}

If the first rationale sees the IFI as a technocratic tool that can mitigate deficit bias through a strategy of de-politicisation, the second rationale understands the office in terms of an institutional response to the decline of legislative influence in the budget process, and is as such arguably a strategy of re-politicisation. Its starting point is the observation that the executive now typically controls the budget process. This new executive financial hegemony has implications for the democratic ideal of elected legislators checking and controlling government tax and spending policies. From this perspective, the primary goal of the IFI is to enhance the fiscal capabilities of the legislature.

Articulating this rationale, Allen Schick offers a long-term narrative according to which legislatures initially wrested control over executive (usually the monarch's) spending through appropriations legislation until the expansion of government altered the balance of financial power. The result was that budgeting came to be viewed as a core function of the executive (aided by its growing bureaucratic apparatus). ${ }^{23}$ Joachim Wehner subjects the constitutional notion that legislatures control the power of the purse to rigorous comparative quantitative and qualitative examination and concludes that, with the exception of the United States, legislatures within the OECD often have a low ability to scrutinise, influence and shape budgets. ${ }^{24}$

Observations of this sort have led to calls for a redefined role for legislatures in tackling debt and deficit, ideally in a manner that is not hostile to the service delivery demands of citizens. Schick calls for a strengthened legislature capable of 'promoting fiscal discipline, improving allocation of public money, and stimulating administrative entities to manage their operations more efficiently. ${ }^{25}$ These insights often cash out in terms of the need to provide non-partisan analysis to legislators in order to 'break the executive's monopoly on budget information'. ${ }^{26}$ The IFI can be modelled as an institution that can help legislators by simplifying complex executive

Posner and Matthew Sommerfield, 'The Politics of Fiscal Austerity: Democracies and Hard Choices' (2013) 13 OECD Journal on Budgeting 141.

23 Allen Schick, 'Can National Legislatures Regain an Effective Voice in Budgetary Policy?' (2002) 1 OECD Journal on Budgeting 15. For the 'long history' of this topic see Carolyn Webber and Aaron Wildavsky, A History of Taxation and Expenditure in the Western World (New York: Simon and Schuster, 1986) and, specifically from the perspective of British constitutional history, Paul Einzig, The Control of the Purse: Progress and Decline of Parliament's Financial Control (London: Secker \& Warburg, 1959).

${ }^{24}$ Joachim Wehner, Legislatures and the Budget Process - The Myth of Fiscal Control (London: Palgrave

Macmillan, 2010). The UK Parliament performs particularly poorly in this comparative examination.

25 Schick, 'Can National Legislatures Regain an Effective Voice in Budgetary Policy?', 28.

${ }^{26}$ John K. Johnson and Rick Stapenhurst, 'Legislative Budget Offices: International Experience' in Rick Stapenhurst, Riccardo Pelizzo, David M. Olsen, Lisa von Trapp (eds), Legislative Oversight and Budgeting: A World Perspective (Washington DC: World Bank, 2008), 152. 
proposals, thereby enhancing the credibility of forecasts (through greater contestability) and promoting fiscal transparency and accountability. ${ }^{27}$

More specifically, some argue that the IFI can reduce two types of information asymmetry. First, principal-agent information asymmetry can be improved. ${ }^{28} \mathrm{By}$ opening up the budgeting process, the IFI can create a more capable principal (the citizens) who, better informed by the expert and independent bystander, is able to use their voting power to reward good policy or sanction bad policy on the part of its agent (the government). Second, legislature-executive information asymmetry: the problem being that the executive has enormous resources (including expert resources) at its disposal, while the legislature typically does not. One way of responding to this problem is to provide a greater range of independent fiscal information either by providing a legislative-aligned IFI or by means of an official forecaster independent of the executive. ${ }^{29}$

\section{DESIGN VARIATION}

While it is legitimate to talk about the IFI in the singular, it is important to acknowledge considerable flexibility in design. IFIs form a 'heterogenous group', as one might expect, that 'vary considerably in terms of their governance provisions, breadth of their mandate and functions, leadership and staff arrangements, and budget.' ${ }^{30}$ Path-dependency is a strong factor, as it almost always is in the context of agency design where local needs and the local institutional environment remain paramount. For member states within the Euro area, initiatives take place within the relatively specific terms of EU regulatory structure developed under the TSCG. ${ }^{31}$ Elsewhere, design choices - as well as being influenced by more mundane political factors - often come down to which of the rationale(s) for the IFI attracted more institutional support at the time of conception.

Von Trapp et al identify three basic models of IFI: the fiscal council, which tend either to be small councils comprised mainly of academics (e.g. Sweden, Ireland) or follow a corporatist tradition in that members of a larger council are proposed by different stakeholders (e.g. Austria, Denmark); the parliamentary budget office, where the focus is on assisting parliamentary oversight of the budget and supporting the

\footnotetext{
${ }^{27}$ Barry Anderson, 'The Value of a Nonpartisan, Independent, Objective Analytical Unit to the Legislative Role in Budget Preparation' in Stapenhurst et al, Legislative Oversight and Budgeting.

28 See e.g. Debrun, 'Democratic Accountability, Deficit Bias and Independent Fiscal Agencies'.

${ }^{29}$ For a good discussion and summary of the literature see Hagemann, 'How Can Fiscal Councils Strengthen Fiscal Performance?'. See also George Kopits, 'Independent Fiscal Institutions: Developing Good Practices' (2011) 11 OECD Journal on Budgeting 3.

${ }^{30}$ See von Trapp et al, 'Principles for Independent Fiscal Institutions and Case Studies', 13.

31 Although even here, considerable variation is to be found. Compare e.g. the French High Council for Public Finances (HCFP), closely networked with the existing Court of Auditors, and which has a direct (if non-binding) role in the budget process but no role in assessing the status and outlook - or sustainability of public finances, with the Spanish Independent Authority for Fiscal Responsibility (AIReF), which enjoys a broad mandate to ensure effective compliance by all public administrations with the budgetary stability principle established by Article 135 of the Spanish Constitution. This includes the continuous role of the budgetary cycle and public indebtedness, as well as analysis of economic forecasts. See von Trapp et al, 'Principles for Independent Fiscal Institutions and Case Studies', 118-23 and 214-9.
} 
work of the main budget committee (e.g. Canada, United States); and the audit model, in which the IFI is an autonomous part of the national audit institution (Finland, France).32

What is common to these models is that the institutions they model are not simply a functionary of the existing fiscal policy arm of the state (the Treasury or Finance Ministry). In design terms, they represent various (path-dependent) attempts to establish an entity with fiscal responsibilities that inputs into government at the highest level but remains free from direct political control or interference. IFIs are structured so as to incline voters and decision makers of today to give more weight than they otherwise might to the impact their vote or decision will have on the fiscal situation future generations are likely to encounter.

\section{UNITED KINGDOM: THE OFFICE FOR BUDGET RESPONSIBILITY}

The genesis of the OBR in many ways reflects the overall story of the rise of the IFI. Established after the GFC in response to local political concerns, the OBR was designed to address structural problems with the existing framework for maintaining fiscal discipline and prevent unsustainable public debt. The OBR also has some unique design features, notably its responsibility for supplying official fiscal and economic forecasts.

\section{ORIGINS}

The OBR grew out of a critical account of the fiscal performance of the previous (Labour) government pre- and post-GFC. The Conservative Party argued in the lead up to the 2010 general election that previous Treasury economic and fiscal forecasting had been too optimistic, ${ }^{33}$ an argument supported by the Institute for Fiscal Studies (IFS). ${ }^{34}$ The central claim was that the Labour government, assisted by this supposed forecasting bias, had overspent in the boom years, leaving state finances less well prepared when the crisis arrived and causing higher public debt as a result. ${ }^{35}$ Existing fiscal rules established by the Treasury as self-binding mechanisms against such a scenario, which were in any case suspended in late 2008 as the GFC started to bite, were now seen as insufficient. ${ }^{36}$ Given this narrative, the

\footnotetext{
32 von Trapp et al, 'Principles for Independent Fiscal Institutions and Case Studies', 13.

33 Conservative Party, 'Reconstruction: Plan for a Strong Economy' (Conservative Party, London, 2008).

34 See e.g. Institute for Fiscal Studies, 'The IFS Green Budget, January 2008' (Institute for Fiscal Studies, London, 2008). The IFS is a politically non-aligned economic research institute that specialises in UK taxation and public policy.

35 See e.g. Robert Chote and Simon Wren-Lewis, 'United Kingdom: Fiscal Watchdog and Official Forecaster' in Kopits, Restoring Public Debt Sustainability, 235.

36 The Labour-led governments of 1997-2010 committed itself to two main fiscal rules: the golden rule that 'over the economic cycle, the Government will borrow only to invest and not to fund current spending'
} 
creation of an arms-length body embedded within the interstices of fiscal administration but distinguished by its sole interest in fiscal responsibility must have seemed a natural progression.

\section{LEGAL STATUS AND FUNCTIONS}

The OBR was established (initially on an interim basis ${ }^{37}$ ) on the formation of the Conservative-led Coalition Government in 2010,38 with the primary 'objective of removing any possibility of political interference from official forecasts' ${ }^{39}$ Taking up its forecasting functions, the OBR became the first IFI anywhere to be charged with making official fiscal and economic forecasts. The Budget Responsibility and National Audit Act 2011 (Budget Responsibility Act) put the OBR on a permanent footing, with former IFS Director and economic journalist Robert Chote as chair. ${ }^{40}$

The OBR is an executive non-departmental public body or executive agency. It is primarily responsible to government not Parliament, but is an independent, arms-length entity. As its sponsor department is the Treasury, it is the Chancellor of the Exchequer who accounts for the OBR's business in Parliament. The Chancellor also appoints the chair and the two other members of the Budget Responsibility Committee, the unit that heads the OBR. ${ }^{41}$ An Oversight Board, comprising the three members of the BRC plus two non-executive members, ${ }^{42}$ and an Advisory Panel of economic and fiscal experts (mostly academics and financial practitioners) complete the corporate structure.

The House of Commons Treasury Select Committee (Treasury Committee) must approve those appointments ${ }^{43}$ and more generally has oversight over the OBR. For a select committee to have a veto power over appointments and

\footnotetext{
and the sustainable investment rule that 'over the economic cycle, the ratio of net public sector debt to GDP will be set at a stable and prudent level' (defined by the Treasury as no more than $40 \%$ of GDP): Finance Act 1998, Part VI; UK Government, 'Code of Fiscal Stability: Budget 1998' (March 1998). The framework was largely retrospective and the Government could also gain fiscal leeway through its determination on the dates on which the economic cycle started and finished. Pre-2010 arrangements did not, then, address the potential 'time inconsistency' problem noted in our conceptual introduction. For analysis see Carl Emmerson, Chris Fayne and Sarah Love, 'The Government's Fiscal Rules' (Institute of Fiscal Studies Briefing Note No.16, November 2006).

${ }^{37}$ HM Treasury Press Notice, 'Chancellor announces policy on fiscal credibility', 17 May 2010.

${ }^{38}$ For its place within the Coalition agreement see Paul Johnson and Daniel Chandler, 'The Coalition and the Economy' in Anthony Seldon and Mike Finn (eds), The Coalition Effect, 2010-2015 (Cambridge: Cambridge University Press, 2015).

${ }^{39}$ Sir Alan Budd, 'Letter to the Chancellor: Advice on the Establishment of OBR as a Permanent Body', 12 July 2010 , para 7.

${ }^{40}$ Chote remains chair at the time of writing, having been reappointed for another 5 -year term in September 2015.

${ }^{41}$ At the time of writing, the other two members of the BRC are former Deputy Governor for Monetary Policy at the Bank of England Professor Sir Charlie Bean and Graham Parker CBE, who had worked previously at the Treasury, the Inland Revenue and the IMF. The latter steps down in August 2018, to be replaced by Andy King, civil servant and currently Chief of Staff at the OBR.

${ }_{42}$ Currently Christopher Kelly (career civil servant) and Bronwyn Curtis (global financial economist and consultant).

43 Budget Responsibility Act, Schedule 1, s.1.
} 
dismissals is extremely rare in the UK context, ${ }^{44}$ and gives the Treasury Committee more leverage in its dealings with government in relation to the OBR. 45 The OBR is supported by a staff of 27 permanent civil servants, which makes the body relatively small both within the IFI context and compared to other domestic institutions - the Office for National Statistics, for instance, has a staff of over 3000 staff. While there are efficiency arguments for making the body no bigger than necessary, it may impact on perceptions of independence, as we shall see.

The fact that the OBR is accountable to both Government and Parliament has perplexed some commentators (we think without good reason). The first external review, ${ }^{46}$ conducted in 2014 by former Canadian Parliamentary Budget Officer Kevin Page, found that 'the OBR's legally defined sources of accountability (the Chancellor and Parliament) are in tension, challenging its independence'. ${ }^{47}$ But this double-headed accountability is not at all unusual within the UK agency context, where agencies tend to work for government but within a set of accountability conventions structured around the principle of Parliamentary democracy. It nonetheless serves to highlight the dual nature of the OBR as an institution of government that aspires to be both a service provider and an accountability mechanism.

The 2011 Act mandates the OBR 'to examine and report on the sustainability of the public finances'. ${ }^{48}$ In fulfilling this duty the OBR must (1) produce the official five-year economic and fiscal forecasts twice a year" ${ }^{49}$; (2) assess the government's progress in achieving its fiscal targets alongside its forecasts; (3) assess the accuracy of its previous forecasts; ${ }^{50}$ and (4) analyse the long-term sustainability of the public

\footnotetext{
${ }^{44}$ Indeed, it was the Treasury Committee itself, in a 2010 Report, that suggested this innovative veto mechanism over BRC appointments and dismissals, thereby exerting a critical influence over the OBR's design: House of Commons Treasury Committee, 'Fourth Report of Session 2010-11 Volume I - Office for Budget Responsibility' (21 September 2010), p.3.

45 The Treasury Committee has not been shy in exerting its influence to ensure non-interference with the OBR's functions. See e.g. 'Treasury Select Committee raises red flags after emails reveal Treasury meddling with Office for Budget Responsibility (OBR)', City AM, 22 February 2016.

46 An external review of the OBR must be undertaken at least once every 5 -year period: Budget Responsibility Act, Schedule 1, s.16.

${ }^{47}$ Kevin Page, 'External Review of the Office for Budget Responsibility' (September 2014), 34.

Recommendation 4 of that Review noted that 'the particularly narrow legal framework of the OBR and its interdependencies with the executive branch may risk creating perceptions of conflicts-of-interest'. 48 Budget Responsibility Act, s.4(1). The Act also requires the Government to produce a Charter of Budget Responsibility (s.1), a Treasury document laid before the House of Commons and brought into force by a resolution of the Commons, which sets out the Government's approach to fiscal policy, management of the National Debt, and guidance to the OBR about how it should perform its legislative duties. This and other documents are supplemented with a number of other primary governance documents, including a Memorandum of Understanding between the OBR and the Treasury (and HM Revenue and Customs, the Department for Work and Pensions) on the joint governance, management and development of the macroeconomic model used by both the OBR and Treasury in forecasting. 49 These forecasts are published in the OBR's Economic and Fiscal Outlook (EFO) publication. Its spring EFO is published at the same time as the budget and incorporates the impact of any tax and spending policy measures announced in the budget.

50 The Treasury Review of the OBR recommended that the OBR should work systematically with forecasting departments on model development, building on existing practice to ensure key models are fit for practice.
} 
finances, based on 50-year projections. ${ }^{51}$ The OBR can also undertake analysis on its own initiative. While its focus is on the public finances at a UK-wide level, the UK government also asks the OBR to forecast the receipts from taxes it has devolved, or intends to devolve, to the Scottish and Welsh governments.

This set of functions indicates that the OBR tacks towards the first rationale outlined in the previous section. It aims to tackle 'deficit bias', specifically by targeting economic forecasting bias (the tendency among governments to overoptimism in their economic forecasting) by the simple expediency of taking that responsibility from the hands of Government altogether. ${ }^{52}$

The other critical task at Budget time for the OBR, beyond forecasting, is certifying the Government's costings. The principal legal restriction on the OBR is the prohibition on alternative policy analysis. (At his Treasury Committee preappointment hearing, Chote argued that OBR independence would be better served by allowing it to respond to costings requests from other political parties. ${ }^{53}$ ) While the Budget Responsibility Act prescribes that where 'any Government policies are relevant to the performance' of its duties, the OBR must have regard to those Government policies only, it notes specifically that the OBR 'may not consider what the effect of any alternative policies would be. ${ }^{54} \mathrm{Th}$ is is a subtle provision, but marks an important difference between the OBR and some other IFIs, including the PBO as we shall see. This restriction on the OBR can be explained in part by the political controversy surrounding the Government's austerity programme, instigated at the same time as the OBR was formed. Had the OBR been able to analyse not just that programme 'but also the more gradual tightening proposed by the opposition, it would have been at the centre of political debate' and may well as a result 'have lost the appearance of impartiality. ${ }^{5}$

The prohibition on alternative policy costing precludes the OBR from producing election policy costings, which is a major function of the PBO. There is an ongoing debate about whether the OBR's remit should be expanded to include the certification of costings of political parties' tax and spending policies in the runup to general elections. The OBR itself (perhaps unsurprisingly) seems keen to expand its remit in this direction, believing that independent scrutiny of pre-election policy proposals could contribute to better policy making, a more informed public debate, and facilitate coalition-formation when party programmes need to be reconciled. ${ }^{6}$ A 2015 Treasury review of the OBR concluded that 'the costs of relaxing the restricting on alternative policies are likely to outweigh the benefits at this stage, and by potentially undermining the OBR, it may serve to reduce rather

\footnotetext{
51 Budget Responsibility Act, s.4.

52 There is a point of possible convergence between the UK and Australia, since it is now Labour Party policy for the $\mathrm{PBO}$ to be granted an official forecasting role in addition to its existing functions.

53 'Robert Chote tells MPs: open OBR to all parties', The Telegraph, 17 September 2010.

${ }^{54}$ Budget Responsibility Act, s.5(3), emphasis added.

${ }^{55}$ Chote and Wren-Lewis, 'United Kingdom: Fiscal Watchdog and Official Forecaster', 243.

${ }^{56}$ See Letter from Robert Chote (Chair of the OBR) to Andrew Tyrie (Chair of the Treasury Committee), 'The costing of pre-election policy proposals', 15 January 2014.
} 
than increase fiscal credibility in the UK. ${ }^{57}$ Responding to this review, the Treasury Committee accentuated the positive aspects of the proposal, while ultimately leaving the matter an open question for further consideration. 'The benefits to fiscal credibility of the OBR carrying out party policy costings before general elections are now becoming clear', it said, and cited with approval the Institute for Government's balanced argument in favour of the move. ${ }^{58}$

The legal structure of the OBR contains a number of mechanisms aimed at shoring up the OBR's independence and impartiality. The primary legislation stipulates that the OBR 'has complete discretion' in performing its main forecasting duty but 'must perform that duty objectively, transparently and impartially.' 59 The Charter of Budget Responsibility, which sets out the OBR's remit, contains a number of independence-related provisions. These relate to forecasting methods, content of publications, work programme and own-initiative research. The Budget Responsibility Act provides a right of access 'to all Government information which it may reasonably require for the purposes of the performance of its [main] duty'.60 The Framework Document, a more detailed governance and management specification, states that the OBR's duty to work 'objectively, transparently and on the basis of government policy' fundamentally 'protects the independence of the OBR and ensures a clear separation between analysis (which is the role of the OBR) and policy-making (which is the responsibility of ministers). ${ }^{61}$

The absence of a guarantee in respect of the OBR's budget in the framing legislation (or the Charter) is sub-optimal from the perspective of securing an IFI's autonomy, as the Page Review noted. ${ }^{62}$ A five-year funding allocation from the Treasury was agreed in 2016-17.63 This reduces the possibility of politically motivated budget fiddling. BRC members are restricted from engaging in 'controversial political activity' as part of their terms of employment.

But the OBR's reasonably robust legal and corporate structure (input legitimacy) ${ }^{64}$ is complicated by aspects of its working life (output legitimacy). The objective of holding government to account may be tempered by the reality that in

${ }^{57}$ HM Treasury, 'HM Treasury review of the Office for Budget Responsibility', 3 September 2015, para 3.92 .

${ }^{58}$ House of Commons Treasury Committee, 'Reviewing the Office for Budget Responsibility' (Seventh Report of Session 2015-16, 9 February 2016), paras 45, 50 \& 54.

59 Budget Responsibility Act, s.5.

${ }^{60}$ Budget Responsibility Act s.9(1).

${ }^{61}$ HM Treasury, 'Office of Budget Responsibility and HM Treasury Framework Document' (May 2014), at 1.7 .

62 'External Review', p.32.

${ }^{63}$ Letter from the Treasury Permanent Secretary to OBR Chair (31 March 2016).

${ }^{64}$ As Gillian Metzger notes, calibrating agency independence can be a complicated affair in which many variables are in play 'including budgetary autonomy, bipartisan and multimember composition, and the extent of substantive oversight in addition to removal protection': 'Through the Looking Glass to a Shared Reflection', 134. We might also note that independence is only one variable when assessing an agency's overall social value (e.g. its fit within a pre-existing administrative network; structures of accountability; constitutional principles). On the importance of 'background conditions' in agency design in the financial regulation context see Cristie Ford, 'New Governance in the Teeth of Human Frailty: Lessons from Financial Regulation' (2010) Wisconsin Law Review 441. 
providing economic forecasting the OBR performs what has hitherto been seen as a basic function of modern government. The tension that ensues is captured in the last line of the Government response to the Treasury Committee 2010 Report: 'The Government agrees that the OBR should not run education campaigns.' ${ }^{65}$ While it was never intended that the OBR run campaigns, the line is indicative of a view that while the OBR should publish 'user-friendly' reports, it ought not to go out of its way to educate the public. The stronger this sentiment, the more the OBR begins to resemble a mechanism internal to government rather than a tool to enhance democratic decision-making.

The prevailing practice among existing IFIs was for an independent body which comments on government forecasts or produces its own forecasts. The OBR broke that mould in that it was set up to provide forecasts for the government. But that role means that the OBR inevitably operates close working relationships with various government departments, above all the Treasury. The OBR, with its small permanent staff, relies on extra staffing largely seconded from the Treasury during forecasting periods in particular. ${ }^{66}$ The sense of a revolving door between OBR and the Treasury has the potential to undermine perceptions of independence. The Treasury Committee in its 2016 Report homed in on the opportunity enjoyed by Ministers to offer views to the OBR during the pre-release access period of the Economic and Fiscal Outlook. If the OBR 'is to remain demonstrably institutionally independent', the Committee concluded, 'the terms of engagement with Government departments must be clarified. At a minimum, a revised Memorandum of Understanding should explain the purpose of exceptional pre-release access, which Ministers and officials are granted access and why, and the sort of changes to OBR documents that are envisaged during this period.' 67

\section{LINES OF DEVELOPMENT}

In its early years, the emphasis of the OBR appears to have been more on independent and impartial service delivery rather than on developing an expert and external 'check' on government. This is a familiar pattern for an early-career IFI. Chohan and Jacobs identify two basic functions such a body might perform. IFIs 'can be relegated to a perfunctory and mechanical role of costing policies that are brought to them' by government or political parties (the mechanistic-costing role). Alternatively, IFIs can also provide 'a more active engagement, a presentation of budget options, and sense of "right" policies in a variety of fields' including government borrowing and expenditure (the normative-advisory role). The authors see the latter role as 'more advanced, and more valuable, but also more politically

65 'Government Response to the House of Commons Treasury Committee $4^{\text {th }}$ Report of Session 2010-

11: Office for Budget Responsibility' (November 2010), at 5.20.

${ }^{66}$ For details see 'HM Treasury review of the Office for Budget Responsibility', paras 5.30-5.31.

${ }^{67}$ Treasury Committee, 'Reviewing the Office for Budget Responsibility', para 37. 
contentious'.68 The OBR, as currently modelled, sits squarely within the former category.

Despite its relatively limited remit, the OBR has not been free from controversy. We have already noted the Treasury Committee's concern for the independence of the OBR from Government (especially the Treasury). That investigation was triggered by the revelation that the Government had used the prerelease access period as an opportunity to induce not entirely insignificant changes of language from the Economic and Fiscal Outlook in late 2014. As well as the robust Treasury Committee Report, the incident also brought critical headlines. ${ }^{69}$ The OBR has also received criticism for the quality of its economic forecasting. Generally, this has concerned its predictive capacities: in its early years (2010-12) its growth forecasts were over-optimistic; later on (2012-14) they proved to be more negative than the actual figures. ${ }^{70}$ More sophisticated criticism has targeted modelling blind-spots. Future spending on welfare and other benefits is calculated independently by the OBR by projecting forward the costs of current policies. For other Departmental spending, the OBR effectively uses the Chancellor's numbers, regardless of whether they are compatible with the Government's current detailed spending policies, undermining to some extent the robustness of the relevant OBR forecasts. ${ }^{71}$

These sorts of criticisms go largely with the grain of the institution, in that they accept that the OBR can in principle produce 'public value' through exerting government numbers on present and future public expenditure to rigorous examination. ${ }^{72}$ It is not necessarily implausible to count them as symptoms of success. They show that the OBR has not been ignored - though perhaps given its official forecasting role it is not really ignorable, especially given economic conditions since 2010. If the OBR is to realise any of its aims, whether improving efficiency or raising the level of transparency and accountability in the budget process, then it really has to be in the public eye. The friction generated by at least some of these critical moments may facilitate productive reform of the institution.

\section{AUSTRALIA: PARLIAMENTARY BUDGET OFFICE}

As noted in the introduction, there has been a notable increase in the number of IFIs since the GFC (especially within the Eurozone). But we also observed that the

\footnotetext{
${ }^{68}$ Usman W. Chohan and Kerry Jacobs, 'Public Value in Politics: A Legislative Budget Office Approach' (2017) 40 International Journal of Public Administration 1063, 1064.

${ }^{69}$ See e.g. 'Treasury has sought to meddle with OBR forecasts', The Times, 14 September 2015.

70 See e.g. 'Four times the OBR has been wrong', The Telegraph, 24 November 2016.

${ }^{71}$ Julian McCrae, 'Securing the long-term credibility of the OBR: four key changes are needed', Institute for Government, 30 November 2015.

72 Chohan and Jacobs, 'Public Value in Politics: A Legislative Budget Office Approach'. The underlying source of this approach is Mark Moore, Creating Public Value: Strategic Management in Government (Cambridge, MA: Harvard University Press, 1995).
} 
impetus underlying the creation of such institutions is both longer term and more general, aided in no small measure by international and transnational governmental institutions such as the $\mathrm{G} 20^{73}$ and the $\mathrm{IMF} .{ }^{74}$ Australia provides an interesting example in this context. Its Parliamentary Budget Office, while it dates from the relevant period - it commenced operations on 23 July 2012 - has almost nothing directly to do with the GFC, which left Australia largely unscathed. The immediate context for the genesis of the PBO was political deal making involving a Labour Prime Minister without a majority courting a supply agreement from independent parliamentarians. One of the things those MPs wanted, and which the Prime Minister was prepared to grant, was an interesting example of the parliamentary budget office model of IFI.

The catalyst for the PBO may have arisen out of the need to form a working majority, but the primary impetus behind its creation was the perceived need (at least among some independent MPs) for greater fiscal transparency and accountability regarding the cost of election promises and more broadly costings outside of an election period requested by independents. One of the key issues was that while the government, opposition, and any minority party with at least 5 elected members enjoyed access to the Ministry of Finance and Treasury to cost their election commitments under the Charter of Budget Honesty Act, similar access was not available to smaller political parties or independents, an important feature of the modern Australian political landscape. ${ }^{75} \mathrm{~A}$ secondary impetus came from the view among some that Parliament would benefit from specialised and independent research and analysis on fiscal and economic policy.

\section{ORIGINS}

The 2010 general election resulted in a hung parliament. As part of the negotiation process between the Labour Party (ALP) and the cross-bench independents, a deal was struck between the then leader of the ALP, Julia Gillard, and two independent MPs, Rob Oakeshott and Tony Windsor, which agreed a set of reforms to the parliamentary process. Some of these reforms were for additional resources for Parliament. This agenda included reform 16.1: that a Parliamentary Budget Office 'be established, based in the Parliament Library, to provide independent costings, fiscal analysis and research to all members of parliament, especially non-government members. The structure, resourcing and protocols for such an Office be the subject of a decision by a special committee of the Parliament

\footnotetext{
73 See e.g. Mathias Dolls, Andreas Peichl and Klaus F. Zimmermann, 'A challenge for the G20: Global debt brakes and transnational fiscal supervisory councils' (2012) 47 Intereconomics 31, discussing inter alia the steps taken on this front at G20 conferences in Seoul and Toronto in 2010 and Cannes in 2011.

${ }^{74}$ See e.g. IMF, Fiscal Councils: Rationale and Effectiveness (IMF Working Paper 16/86, International Monetary Fund, April 2016).

75 Charter of Budget Honesty Act 1998 (Cth), Parts 2 \& 8.. For a recent explanation of how this process operates, including interaction with the PBO, see Joint Secretaries of the Treasury and Department of Finance, Charter of Budget Honesty Policy Costing Guidelines, Treasury, 2016

(https://static.treasury.gov.au/uploads/sites/1/2017/06/charter-of-budget-honesty-guidelines.pdf)
} 
which is truly representative of the Parliament. ${ }^{76}$ A Joint Select Committee on the Parliamentary Budget Office was appointed, reporting in March 2011. The Government agreed or agreed-in-principle to all of its 28 recommendations in July. The agreement included allocating $\$ 24.9$ million over 4 years in the 2011-12 Budget to establish the $\mathrm{PBO},{ }^{77}$ a provision which makes it one of the most effectively endowed budget institutions in the world. ${ }^{78}$

Its functions and organisational arrangement indicate that, in contrast to the OBR, the PBO tacks towards the second rationale for IFIs outlined earlier. Its immediate goal is to address 'information asymmetry' associated with the politics of modern public financing, specifically by empowering both minority parties and independents within Parliament and Parliament more generally through the provision of specialised, independent fiscal information. This is not to say, of course, that countering the problem of 'deficit bias' (Rationale 1) is not present in these arrangements as an underlying goal.

\section{LEGAL STATUS AND FUNCTIONS}

The PBO was established by the Parliamentary Service Amendment (Parliamentary Budget Officer) Act 2011 (which amended a number of pieces of legislation, most notably the Parliamentary Service Act 1999) as one of four parliamentary departments supporting the Australian Parliament. ${ }^{79}$ Its primary clients are parliamentarians. Accountability to Parliament is secured in the first instance through the appointments process. The PB Officer is appointed (and can only be removed) for a four-year term by the Presiding Officers, i.e. the Speaker of the House of Representatives and the President of the Senate, following approval by the Joint Committee of Public Accounts and Audit ('the Committee'). ${ }^{80}$ The legislation also grants significant oversight powers to the Committee, which has a duty to consider the PBO's annual work plans and budget. ${ }^{81}$

Unlike the OBR whose primary functions concern forecasts and budget estimates, the PBO is specifically prohibited from preparing economic forecasts or preparing budget estimates, whether at the government, agency or programme level. ${ }^{82}$ Rather its mandate is 'to inform the Parliament by providing ... independent and non-partisan analysis of the budget cycle, fiscal policy and the financial

\footnotetext{
76 See the Australian Labour Party and the Independent members (Mr Tony Windsor and Mr Rob Oakeshott) - Agreement, 7 Sept. 2010, and 'Appendix B: Agreement for a Better Parliament Parliamentary Reform'

77 Government Response to the Joint Select Committee on the Parliamentary Budget Office Inquiry into the Proposed Parliamentary Budget Office, July 2011.

78 Usman W. Chohan, 'How does Australia's policy costings body, the Parliamentary Budget Office, compare?', The Conversation, June 2016.

79 Parliamentary Service Act 1999 - as amended by the Parliamentary Service Amendment (Parliamentary Budget Officer) Act $2013-$ s.64A.

80 s.64X.

81 s. $64 \mathrm{~S}$.

${ }^{82}$ s.64E(2).
} 
implications of proposals. ${ }^{83}$ This translates into two more specific functions: (1) election policy costings; and (2) policy costings on request by senators and members.

(1) The election policy costings function is a distinctive feature of the Australian version of the IFI. A survey of OECD countries found only one other jurisdiction - the Netherlands - where the IFI has a role in costing elections. ${ }^{84}$ This part of its mandate equates to two powers, the first being a power for parliamentarians to request that a policy be costed on a public basis during the 'caretaker period' leading up to polling day. The second is a mandatory reporting requirement, a responsibility introduced in $2013^{85}$ which requires the PBO 'to report on election commitments of designated Parliamentary parties' within 30 days of the end of the caretaker period of a general election. The report must set out for each designated parliamentary party costings of (a) all election commitments that would have 'a material impact on the Commonwealth budget sector and Commonwealth general government sector fiscal estimates' and (b) 'the total combined impact those election commitments would have on the Commonwealth budget sector and Commonwealth general government sector fiscal estimates' over the next 4 financial years.

In practice this entails that each party must, before $5 \mathrm{pm}$ on the day before polling day, give the PBO a list of the policies that the party has publicly announced it intends to seek to have implemented after the election. The ensuing report must be publicly released. This means that when parties announce a policy, with their own costing, they know that it will be subject to serious post-election scrutiny by an independent body. As then Treasurer Wayne Swan observed during the second reading of the 2013 legislation: "The Bill will impose discipline on the promises of political parties and incentivize all political parties to be up front and honest about the cost of their promises. ${ }^{\prime} 86$

The fact that the scrutiny of costings proposals occurs after polling day may look curious, causing a sceptic to wonder how the PBO can influence a vote if its work on election policies only comes out after the election. It is true that the arrangement represents a trade-off between, on one hand, the goal of encouraging fiscal responsibility in election promises and, on the other, the over-politicisation and the over-exposure that would ensue if the PBO could put out a statement shortly before election day confirming or dismissing the purported costs of a party's election policies ( $c f$ Former FBI Director James Comey's intervention in the 2016 US Presidential election is a cautionary tale ${ }^{87}$ ). The PBO may still exert influence, casting a shadow over campaigning. That presence, more particularly the sanction

\footnotetext{
83 s.64B.

${ }^{84}$ von Trapp et al, 'Principles for Independent Fiscal Institutions and Case Studies', 19 \& 181. Although established in 1945, the tradition has grown since the mid-1980s of requesting costing and economic impact forecasts of election manifestos from the CFB Netherlands Bureau for Economic Policy Analysis. Although voluntary, all major parties now ask for such costings.

85 By the Parliamentary Service Amendment (Parliamentary Budget Officer) Act 2013.

86 Hansard, Thursday 14 March 2013, p. 2093.

87 See for example, Amy Chozick 'Hillary Clinton Blames F.B.I. Director for Election Loss' in New York Times, 12 November 2016, https://www.nytimes.com/2016/11/13/us/politics/hillary-clinton-jamescomey.html
} 
of having the PBO issue a statement 30 days after a party is elected (or even after defeat) to the effect that its costings were seriously in error, provides a nonnegligible incentive to politicians not to make extravagant promises. Financial credibility is a hard-won reputation in the political arena, and easily lost, and a party's reputation for fiscal competence - or incompetence - does not track a single electoral cycle but operates over the medium-to-long term. (Consider how the British Labour Party still suffers from a reputation for fiscal irresponsibility picked up a decade ago.)

(2) The policy costings function involves a requirement on the PBO to prepare responses to requests from individual Senators and Members (and also parliamentary committees) outside the caretaker period, a power that notably includes the preparation of costings in relation to proposed policies and bills. This function might seem on the face of it to enable a party to 'officially' cost another party's policy proposal or initiative. However, in practice this is unlikely. PBO Guidance Note $01 / 2013$ provides that since the PBO must operate at all times in an independent and non-partisan manner, it 'will not prepare costings of policies attributed to an individual parliamentarian or a political party without the knowledge and active participation of the individual parliamentarian or political party in the costings process.' 88

The PBO's fundamental role in relation to this part of its remit, then, is to empower members of opposition parties, and more specifically minor parties, to cost their own policies. Both the guidance notes and the practice of the $\mathrm{PBO}$ as evidenced by its website, which publishes all costings unless requested to be kept confidential, indicates that the key to the PBO's work is power asymmetry between Government (which has the Treasury to hand) and minor parties and independents, especially in the Senate. Much of the costing work concerns proposals that independents or small party Senators put to the PBO often in the context of negotiations with Government on amendments to legislation that they would like to see. The fact that such a request (outside the caretaker period) may be confidential enables parliamentarians and parliamentary parties to develop and cost their policies in a measured fashion in the lead up to an election. They are then able to publicly release policies that have been professionally costed by the PBO.

Again, details of these arrangements may appear counter-intuitive. In particular, if the rationale behind the $\mathrm{PBO}$ is to counteract information asymmetry, the option to keep costings confidential seems odd. That criticism would be more compelling if the $\mathrm{PBO}$ was designed to address information between the public and the executive (principal-agent asymmetry). While this is one of the roles of the PBO - possibly an increasing one - it remains a subsidiary function. Its primary objective is to overcome information asymmetry (and resource asymmetry) between MPs who are not members of a major party, and the elected government (legislature-

88 PBO Guidance Note 01/2013, 'Costing of policy proposals at the request of a parliamentarian or political party that are attributed to another parliamentarian or political party'. 
executive information asymmetry). The possibility of confidential costings does nothing to address public/government information asymmetries but may be part of an effective response to legislature/executive asymmetries. The central innovation is that MPs can now get their hands on genuine costings, when previously this would not have been a realistic prospect.

The PBO's mandate does not extend to oversight of the budget process, although it does include the duty to prepare responses to requests by Senators or Members to the budget. It also has a fairly broad capacity to conduct on its own initiative research on and analysis of the budget and fiscal policy settings. ${ }^{89}$ Exercise of this own-motion power has produced 14 Reports to date, for instance on the budgetary impact of the National Broadband Network ${ }^{90}$ and the Higher Education Loan Programme. ${ }^{91}$ The impression is of an IFI that is busy doing independent policy thinking and forecasting.

Two own-initiative reports on economic forecasting within the budget process are particularly salient. ${ }^{22}$ Although based on the economic forecasts and other parameters underpinning the Budget, analysis in these reports goes beyond the forward estimates contained in the official budget papers prepared by the Treasury (in the more recent report, to the years 2027-28). These 'medium-term' reports are not dissimilar to the 'financial sustainability' reports produced on an annual basis by the OBR.

In the course of its ordinary business, the PBO is under an obligation to use the budget parameters set out by the Treasury, which are considerably shorter than the 50-year horizon deployed by the OBR. Even so, the PBO can be said to have made a concerted effort to insert a level of comparative rigour into the forecasting exercise. It is here that we can see perhaps most clearly the ambition of the PBO to become more than an election policy costing machine, reactive to the wishes of often marginal MPs and Senators. The PBO appears to be engaged, in the exercise of its own private-motion power, in a much broader analysis. It has chosen to examine some of the largest and most contentious areas of policy, ${ }^{33}$ and has done so while projecting their impacts over the forward estimates and undertaking forecasting work over a longer horizon than the Treasury.

\footnotetext{
${ }^{89}$ s.64E(1)(c).

${ }^{90}$ Report 4/2016: National Broadband Network: Impact on the Budget (14 December 2016).

${ }^{91}$ Report 2/2016: Higher Education Loan Programme: Impact on the Budget (6 April 2016).

${ }^{92}$ Report 02/2015: 2015/16 Budget: Medium-term projections and Report 02/2017: 2017/18 Budget: medium-term projections (5 July 2017).

${ }^{93}$ The national broadband network has been one of the most expensive and controversial projects in recent Australian policy making history. See e.g. Tooran Alizadeh, 'The NBN: how a national infrastructure dream fell short' The Conversation, 5 June 2017; Paddy Manning, 'Network Error', The Monthly, April 2017; Karen Middleton, 'The Politics of the NBN', The Saturday Paper, 28 October 2017. Likewise the Higher Education Loan Programme remains a fundamental battle ground between major parties. For a brief history, and the role of the PBO within it, see Julie Hare and Kylar Loussikian, 'Higher education, higher costs in student loan scheme nightmare' The Australian, 8 April 2016.
} 


\section{LINES OF DEVELOPMENT}

While a relatively new entity on the Australian landscape, the $\mathrm{PBO}$ has become a creature of some interest. Two examples demonstrate its increasingly embedded nature. First, in the lead up to the 2016 national election, the Labour Party (by that time in opposition) announced an intention to expand the PBO's remit, specifically by transferring the official forecasting role for the budget from the Treasury to the PBO. As Shadow Treasurer Chris Bowen noted, this innovation would 'ensure that economic forecasts are undertaken at arm's length from government, giving the public more confidence in the budget process'. ${ }^{94}$ Party political considerations naturally played a part in this proposal. Even so, it indicates a deepening commitment to the OBR within the political elite and more particularly an intention to give the institution more responsibility for mainstream fiscal management functions. The effect of such reform would be to bring the PBO closer to the OBR, by adding to its existing rationale of combatting 'information asymmetry' the additional rationale of tackling 'deficit bias'.

In politics as in life, imitation is often the sincerest form of flattery. As a federation, Australia offers plenty of scope for copycat innovation, and there has been a significant uptake of IFIs within state legislatures since the PBO was formed. In late 2010 - after the federal election that led to the establishment of the PBO New South Wales introduced a Parliamentary Budget Officer. Like its federal counterpart, its focus is on election policy costings, with a statutory duration of less than a year before state elections. ${ }^{95}$ In South Australia, the Parliamentary Budget Advisory Service - led by the Parliamentary Budget Officer - operated for the first time at the 2018 state election, although at the time of writing it has no firm statutory underpinning. ${ }^{96}$ The focus of that model is once again non-compulsory election policy costings. Another institution similar in design to the federal PBO has recently been instituted in Victoria. ${ }^{97}$

Entities with a special focus on costings used during the election process are proliferating in Australia. It is reasonable to wonder if the present (and rather

\footnotetext{
94 Chris Bowen, National Press Club Address, May 2016, quoted in Michelle Grattan, 'Aspiring treasurer Chris Bowen looks fit for purpose' The Conversation, 10 May 2016, https://theconversation.com/aspiringtreasurer-chris-bowen-looks-fit-for-purpose-59187.

95 See Parliamentary Budget Officer Act 2010; see also

https://www.parliament.nsw.gov.au/pbo/Pages/Parliamentary-Budget-Office.aspx

96 See http://pbas.sa.gov.au/about

97 Parliamentary Budget Officer Act 2017. The Victorian scheme allows for election related policy costings and will operate at three levels: in the election policy costing period, a parliamentary leader may request the $\mathrm{PBO}$ officer prepare a policy costing (which can then be made public by the leader); if the leader asks for more than one policy to be costed in this period, they may instead request a 'pre-election report' enabling a party to list, and then have costed, those policies they would like costed, with the preelection report going public only at the request of the leader; there is a separate post-election report, under which the PBO Officer must prepare a post-election report on the policies of each parliamentary leader that were publicly announced before the date of the general election. The second plane of this body enables any MP to request a costing of a policy or proposed policy at any time during the parliamentary term.
} 
narrow) focus on election policy costings will persist, or whether their role might expand, influenced by the possible direction of travel of the federal PBO, to include more general fiscal policy advisory functions. Recalling Chohan and Jacob's framework, one possible direction of travel would be from the current staunchly mechanistic-costing role towards a more ambitious normative-advisory role. (Although we might note that such a transition can be met with strong resistance. ${ }^{98}$ )

\section{COMPARATIVE ANALYSIS}

The OBR and the PBO owe their existence to particular confluences of political events. The former represents a key policy initiative connected to a critique of the previous Government's supposedly profligate handling of the public finances, an issue that became especially pressing after the GFC. The latter happened to be one of the demands made by a handful of independent MPs in return for an agreement to supply a minority administration.

For all the serendipity of their origins, the two institutions mirror quite closely the two central rationales underlying the global proliferation of IFIs. The OBR, under the aegis of the executive (albeit with substantial parliamentary oversight and protection) and with a focus on budget forecasting and the long-term sustainability of the public finances, reflects the 'deficit bias' rationale - the idea that governments ought not to be trusted to run the numbers alone (if at all). The PBO, a parliamentary body with a focus on supplying MPs with fiscal information (including important election costings functions), reflects the information asymmetry' rationale - more especially the idea that legislatures should be empowered by making inroads into the executive's fiscal hegemony ('legislatureexecutive information asymmetry').

Once instituted, IFIs are drawn into the game of party political point-scoring. We have just seen how the current Australian Labour Party is seeking to use the $\mathrm{PBO}$ to its advantage. The politics of economic sustainability are equally a source of contestation in the UK. In late 2017, Shadow Chancellor John McDonnell introduced a policy that the government should include the fiscal risks posed by global warming in future economic forecasts. The reform would put climate change on an equal footing with other complex challenges affecting the public finances such as demography. McDonnell also announced that a future Labour Government would give the OBR total independence, allow it to audit party manifestos, and said that the forecaster would report directly to Parliament rather than the Treasury. ${ }^{99}$ This last initiative is particularly interesting. Not only does it provide more evidence for a 'convergence thesis' between the two IFIs - since if it were to occur the OBR would become, like the PBO, in effect a parliamentary budget office. It also indicates the current standing the OBR has among politicians. Given its origins, one could

98 Chohan and Jacobs, 'Public Value in Politics', citing the experience of the Canadian PBO.

99 'Labour vows to factor climate change risk into economic forecasts', The Guardian, 14 November 2017. 
well imagine the Labour Party to take a much less supportive line towards the institution.

Both are young entities, with presumably much growing still to be done. But it looks as though they might be on a path of convergence. The OBR (with the support of the Treasury Committee and some MPs) looks to move into election policy costing, something that is central to the PBO's existing mandate. The PBO looks as though it might gain an official forecasting role should the Labour Party win the next general election, an addition that would align it more closely with the OBR. It is unwise to generate descriptive generalisations or predictions on so limited a case study. But we introduce, very tentatively at this point, a set of hypotheses that we hope to test in future research: (i) whatever its starting point, an IFI will seek to add functions to its portfolio; (ii) these will include both more inward-facing functions (e.g. official forecasting) and more outward-facing functions (e.g. election policy costings); and (iii) this expansion is likely to be facilitated by the logic of interparty competition. The extent to which this process of expansion and alignment is a transnational phenomenon - whether the product of comparative or copycat behaviour and/or as a result of pressure from transnational bodies such as the G20 - is something we will explore in future work.

We have made observations about the immediate take-up in political culture, but a fuller evaluation of an IFI's 'public value' contribution is only plausible over the long term. If we assume that the two IFIs studied in this paper embed themselves in the fiscal pathways of the state, it is possible to detect at least one serious possible downside about their current operations. The existence of an IFI may make it easier for Governments to perform a type of virtue signalling in fiscal affairs. 100 This is particularly likely where an IFI has a limited remit and performs its functions tamely, allowing politicians to talk the talk of fiscal responsibility without really facing up to hard choices. Drawing on recent Australian practice, Chohan and Jacobs observe that the incantation of terms such as fiscal 'sustainability' and 'responsibility' combine with the release of budget documents at regular intervals to give contemporary fiscal politics a ritual flavour. Given the contradictory stance that citizens often have on issues of expenditure and restraint, politicians can be tempted to 'prioritize between those values that will be addressed through resources and those that will be addressed through rhetoric.'101

The intersection between the genesis of IFIs and the rhetoric of fiscal trust politics is revealing. IFIs operate without the hard sanction powers of other gatekeepers - e.g. ratings agencies can increase or decrease the cost of borrowing through a revision of the institution's credit rating - and may be said as such to be

\footnotetext{
100 Critics suggest that this is what has happened in respect of the Irish Fiscal Advisory Council. For evaluation see Lars Jonung, Iain Begg and Michael G. Tutty, How is the Irish Fiscal Advisory Council Performing? An Independent Evaluation of the First Years of IF AC, (Working Paper 2016:3, Department of Economics, Lund University).

101 Usman W. Chohan and Kerry Jacobs, 'Public Value as Rhetoric: A Budgeting Approach' (2017) International Journal of Public Administration 1, 4 \& 10.
} 
incapable of imposing any real costs (beyond rhetorical damage) on the governments they monitor. ${ }^{102}$ This more sceptical line of enquiry prompts the Aristotelian ${ }^{103}$ question: are IFIs merely institutions of deliberative rhetoric, to be deployed (as a sword) in order to dissuade the demos from following a fiscally heterodox politician whose position independent analysis has 'proved' will bring only bad things or (as a shield) against speculative challengers, enabling the politician in power to refute assertions of fiscal incompetence with recourse to 'independent' fiscal truth?

Should the rhetoric (as opposed to the reality) of public value take hold in the arena of budget politics, one could speculate about where that leaves the goal of rebuilding public confidence, the ultimate political goal of the endeavour. Dawn Oliver uses the term 'stewardship' to capture the constitutional role of various armslength public bodies (including the OBR) that provide information or other resources to governments. ${ }^{104}$ But for which constituencies do they act as steward? The obvious (but not quite complete) answer is the public. IFIs may be able to serve an important role in the democratisation of financial governance. As Annelise Riles argues, the technicalities of fiscal decision-making are its core element. To democratise the practice requires political debate to be 'once more technical and more political. Institutions like the OBR and PBO, not least by providing independent and transparent fiscal information, can help bring together 'finance's many publics' into the political debate at the requisite level of sophistication. ${ }^{105}$ But that debate does not only concern today's citizens, who constitute only a small - and perhaps relatively insignificant - part of the political equation. Alessandro Spano observes that 'if a government decides to finance today's expenses with long term debt, a clear intergenerational clash emerges: today's generation is going to enjoy a higher value whose cost will be paid by tomorrow's citizens'. ${ }^{106}$ We argue that IFIs work really in the interests of the citizens of the future, as the exceptionally long timelines through which IFIs tend to think indicate.

From the public law perspective, fiscal sustainability is ultimately a question of intergenerational constitutional justice. The general idea, though sometimes overlooked, is familiar. Burke's idea that the essential constitutional relationship

\footnotetext{
102 But, as Philip Pettit reminds us, 'attitude-dependent goods' - such as trust or good standing - are desirable to agents and so important to society at large. They are also (instrumentally) essential to politicians in order to achieve their goals and ultimately to the state if it is to function effectively: 'The Cunning of 'Trust' (1995) 24 Philosophy \& Public Affairs 202, 212-17. To inflict a sanction on a politician's (or political institution's) good reputation is thus a material cost.

103 Aristotle, Rhetoric, Book I, Ch 3, ss 3-4: 'The deliberative kind [of rhetoric] is either hortatory or dissuasive; for both those who give advice in private and those who speak in the assembly invariably either exhort or dissuade'. With deliberative forms of rhetoric, there is always a focus on the future: 'to the deliberative the future, for the speaker, whether he exhorts or dissuades, always advises about things to come'.

104 Dawn Oliver, 'Constitutional Stewardship: A Role for Public or State Sector Bodies?’ (2017) 15 New Zealand Journal of Public and International Law 21.

105 Annelise Riles, Collateral Knowledge: Legal Reasoning in the Global Financial Markets (Chicago: University of Chicago Press, 2011), 223.

106 Alessandro Spano, 'Public Value Creation and Management Control Systems' (2009) 32 International Journal of Public Administration 328, 333.
} 
takes the form of 'a partnership not only between those who are living, but between those who are living, those who are dead, and those who are to be born'107 still exerts considerable influence. The French mathematician Condorcet, critical of the presentism of much of the incipient democratic theory, provided the prose to Burke's poetry in the form of detailed constitutional specifications for the political value of time. ${ }^{108}$ The IFI represents a similarly detailed and material specification of the classic constitutional task of self-binding. It is a technique aimed ultimately at retying the now unbound fiscal decision maker to the mast by means of fiscal restraints in the interests of future demoi incapable of asserting that capacity but who are the inheritors of current fiscal choices. ${ }^{109}$ The immediate goal is a modest resetting of expectations on present decision makers and, by highlighting the impact current policies will have on the demos of the future, a subtle reminder that in making decisions they bring into view a longer-term horizon.

\footnotetext{
${ }^{107}$ Edmund Burke, Reflections on the Revolution in France [1790].

108 See e.g. Elizabeth F. Cohen, The Political V alue of Time: Citizenship, Duration, and Democratic Justice

(Cambridge: Cambridge University Press, 2018), 68-76.

109 Jon Elster, Uysees and the Sirens: Studies in Rationality and Irrationality (Cambridge: Cambridge University Press, 1979).
} 